\title{
Intertextual-Based Learning Strategy in Salt Hydrolysis Concept to Promote Students' Concept Mastery and Scientific Process Skills
}

\author{
Silvia Anggraini Pohan, Tuszie Widhiyanti*, Sri Mulyani, Wiji Wiji \\ Department of Chemistry Education \\ Universitas Pendidikan Indonesia \\ Bandung, Indonesia \\ *tuszie@upi.edu, srimulyani@upi.edu,maswiji@upi.edu
}

\begin{abstract}
This study aims to obtain information to improve students' mastery of concepts and Science Process Skills with intertextual-based learning using the POE model (Predict, Observe, Explain). The method used is a quantitative method with pre-experimental one group pretest posttest research design. Research subjects were 31 11th grade high school students who had not yet studied salt hydrolysis. Concept mastery data were obtained by pretest-posttest using an intertextual-based diagnostic test with a two-level multiple choice. Science process skills data were obtained by pretest-posttest using 14 Science Process Skills items consisting of $\mathbf{1 0}$ basic Science Process Skills questions and 4 integrated Science Process Skills questions. From the results of the analysis of concept mastery, it is known that of the 31 students, 31 students experienced an increase in concept mastery with the $\mathrm{N}$-gain acquisition distribution of 1 student in the high category, 12 students in the medium category, and 18 students in the low category. From the results of data analysis of science process skills, it was found that students' science process skills had increased from an average of $74.31 \%$ to $81.11 \%$.
\end{abstract}

Keywords: concept mastery, intertextual learning strategy, predict observe explain, scientific process skills

\section{INTRODUCTION}

To overcome the difficulties experienced by students in understanding concepts in chemistry, some of the results of previous studies indicate that learning chemistry must involve levels of macroscopic, submicroscopic, and symbolic representation as well as intertextuality of the three to facilitate and improve students' mastery of concept [1].

Indonesian Ministry of Education and Culture in Indonesia has put their concern in the Standard Process which states that the 2013 curriculum is a competency-based curriculum that emphasizes applicative skills [2]. Based on these demands, chemistry subjects need to develop science process skills [3].

Science process skills also enable students to improve mastery of the concepts they know and complete them to obtain knowledge content in future [4]. The relationship between science process skills and mastery of concept is also strengthened by Brunner's statement which states that in teaching with science process skills approaches the students will use their minds to perform various concepts and principles because in their learning process students will perform mental operations in the form of measurements, predictions, observations, inference and grouping [5]. These mental operations can develop students' ability to form knowledge.

Science process skills are divided into basic science process skills and integrated science process skills. Basic science process skills consist of observing, inferring, measuring, communicating, classifying, and predicting. Integrated science process skills including control variables, defining operationally, formulating hypotheses, interpreting data, experimenting, formulating models, and presenting information [6].

POE learning is a learning model that explores student understanding by requiring students to do three stages, namely Predict, Observe, and explain. At the Predict stage students are asked to predict what will happen to an event or experiment based on the knowledge they already have and then explain the things that underlie the prediction, at the Observe stage students observe and carefully review an event or outcome an experiment to find out the truth of the predictions they have made. In the last stage, explain (explaining), students are asked to express similarities and or differences in predictions with the results of observations, then explain why the phenomenon occurs [7].

Previous study in POE strategy has found that POE-based intertextual learning strategies can improve the mastery of concepts and science process skills [8]. Mastery of student concepts increased from the average pretest score of 39.83 to 79.65 at posttest. $\mathrm{N}$-gain calculation results show that 15 people experienced an increase in the high category and 19 people experienced an increase in the moderate category. Science process skills have also increased from 80.59 to 88.38 . $\mathrm{N}$-gain calculation results show that 6 students experienced an increase in the high category, 12 students had an increase in the medium category, and 16 students had an increase in the low category. Another study which implemented an intertextual strategy shows that intertextual-based strategies can improve 
students' concept mastery with an overall $\mathrm{N}$-gain value of 0.46 , which is in the medium category [9].

One learning strategy that can be developed to achieve competency-based learning that integrates the three levels of chemical representation and science process skills is an intertextual-based learning strategy with the POE model. Intertextual learning strategies using POE models on salt hydrolysis material have been prepared [10] but has not been implemented. Therefore, this research aims to obtain information about the potential of learning strategies in improving students' mastery of concepts and science process skills.

\section{MethoDS}

The research subjects were 31 grade XI high school students who had not studied salt hydrolysis material at one of the state high schools in Bandung. The method used is quantitative methods with a pre-experimental design with one group pretest-posttest design. Pre-experimental design is a design in which researchers study a class and give certain treatment to that class [11]. One group pretest-posttest design notation can be seen in Figure 1.

\begin{tabular}{|c|c|c|}
\multicolumn{1}{c}{ Pretest } & \multicolumn{1}{c}{ Independent } & Postest \\
\hline $\mathrm{Y}_{1}$ & $\mathrm{X}$ & $\mathrm{Y}_{2}$ \\
\hline
\end{tabular}

Fig. 1. One group pretest-postest design.

For the concept mastery question 8 items of the Diagnostic Tests in the form of two-tier items was used the instrument which adopted from the existing model test [12]. The two-tier mental model diagnostic test is a multiple choice question with the first level questions about the concept of the material and the second level the reasons for the first level answers. Question items are made by making the first tier a macroscopic level and the second tier a submicroscopic level. Meanwhile, the science process skills pretest-posttest instrument used was adopted from the items which was developed by Monica [13] and Ngoh [14]. There are 14 questions consisting of 10 basic science process skills items and 4 integrated science process skills items [15]. The distribution of science process skills items can be seen in the table 1 .

TABLE I. Distribution OF SCIENCE PROCESS SKILls ITEMS

\begin{tabular}{|l|l|}
\hline \multicolumn{1}{|c|}{ SPSs Aspects } & \multicolumn{1}{|c|}{ Item Number } \\
\hline Observation & $1-2$ \\
\hline Measuring & $3-4$ \\
\hline Classifying & $5-6$ \\
\hline Predicting & $7-8$ \\
\hline Communicating & $9-10$ \\
\hline Experimentation & $11-12$ \\
\hline Data interpreting & $13-14$ \\
\hline
\end{tabular}

Quantitative data analysis in the form of a percentage and the average value of each data processed into $\mathrm{N}$-gain. The $\mathrm{N}$ gain test can provide a general picture of an increase in learning outcome scores between before and after the intertextual learning strategy is applied with POE. The N-gain formula according to Hake [16], while the N-gain category are shown in the table 2 .

$$
\mathrm{N}-\text { gain }=\frac{\text { posttes score }(\%)-\text { pretest score }(\%)}{\max \operatorname{score}(\%)-\text { pretest score }(\%)}
$$

TABLE II. THE N-GAIN CATEGORY

\begin{tabular}{|l|l|}
\hline \multicolumn{1}{|c|}{ N-gain score } & \multicolumn{1}{c|}{ category } \\
\hline$\geq 0.7$ & High \\
\hline $0.7>\mathrm{N}$-gain $\geq 0.3$ & Medium \\
\hline$<0.3$ & Low \\
\hline
\end{tabular}

\section{RESULTS AND DISCUSSION}

\section{A. Mastery of Concepts After Learning Using Intertextual Learning Strategies With POE on the Concept of Salt Hydrolysis}

The questions used were 8 items. The first level is in the form of answer options A, B, C, D and the second level is in the form of options I, ii, iii, iv, v, and vi. Student answers are grouped into four categories, namely correct and correct answers at the second level (type 11), correct at the first level and wrong at the second level (type 10), wrong at the first level and correct at the second level (type 01), wrong at the second level (type 00).

The concept of salt that can produce an acid solution is seen through three questions namely questions number 1,2 , and 6 . The concept of salt that can produce an alkaline solution is seen through three problems namely questions number 3,4 , and 5 . The concept of salt that can produce a neutral solution is seen through two questions, namely questions number 7 and 8 . Increased mastery of concepts can be seen from the comparison chart of students' pretest and posttest values in the Figure 2.

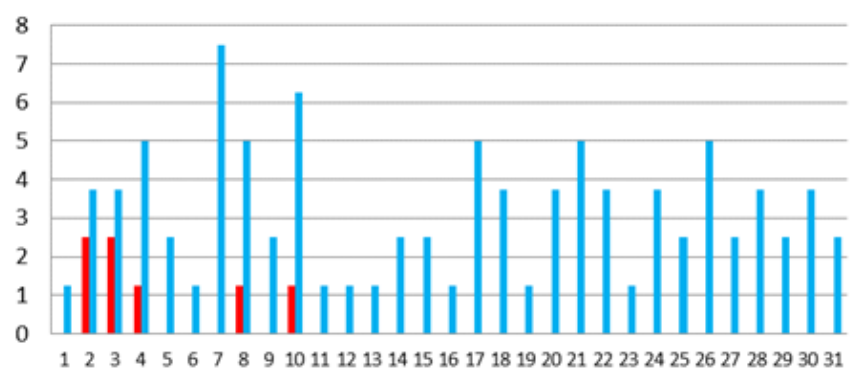

Fig. 2. Comparison Chart of student pre-test and post-test scores (red and blue bars respectivelly).

As seen in the graph above, of 31 students, 31 students experienced an increase in mastery of concepts. From the calculations obtained by $\mathrm{N}$-gain individuals for the results of the pretest and posttest. The distribution of students' gains is 1 student in the high category, 12 students in the medium category, and 18 students in the low category. The number of students in the low category shows the number of students who still do not fully understand the concept of salt hydrolysis at the macroscopic, submicroscopic and symbolic levels. Students in the low category generally understand the concept only at the 
macroscopic level so as to get a low score. The following table $\mathrm{N}$-gain distribution of students.

The diagnostic test instrument used by each item has different item indicators, with different concepts. Therefore, to clarify the presentation of data on the improvement of students 'concept mastery, the students' pretest and posttest data are discussed per question by comparing the percentage of students which answers each type of answer. Indicator items can be seen in table 3 .

TABLE III. INDICATOR OF EACH ITEMS

\begin{tabular}{|l|l|}
\hline Number & \multicolumn{1}{|c|}{ Indicators of items } \\
\hline 1 & $\begin{array}{l}\text { Salt which can produce acid solutions based on their } \\
\text { properties }\end{array}$ \\
\hline 2 & $\begin{array}{l}\text { Salt which can produce acid solutions based on pH } \\
\text { measurement results of the solution }\end{array}$ \\
\hline 3 & $\begin{array}{l}\text { Salt which can produce basic solutions based on their } \\
\text { properties }\end{array}$ \\
\hline 4 & $\begin{array}{l}\text { Salt which can produce base solutions based on the } \\
\text { measurement results of solution pH }\end{array}$ \\
\hline 5 & $\begin{array}{l}\text { Salt which can produce base solutions based on comparison } \\
\text { of } K_{a} \text { and } K_{b}\end{array}$ \\
\hline 6 & $\begin{array}{l}\text { Salt which can produce acid solutions based on comparison } \\
\text { of } K_{a} \text { and } K_{b}\end{array}$ \\
\hline 7 & $\begin{array}{l}\text { Salt which can produce neutral solutions based on their } \\
\text { properties }\end{array}$ \\
\hline 8 & $\begin{array}{l}\text { Salt which can produce neutral solutions based on } \\
\text { measurement results of solution pH }\end{array}$ \\
\hline
\end{tabular}

From the analysis of student answers for each item, it can be seen that the significance of the changes is different for each item that indicates an increase in the concept is quite significant in certain concepts, but not significant for other concepts. To make it easier to see changes in students' mastery of concepts, also made a graph of the distribution of the results of the pretest that can be seen in the Figure 3 and Figure 4.

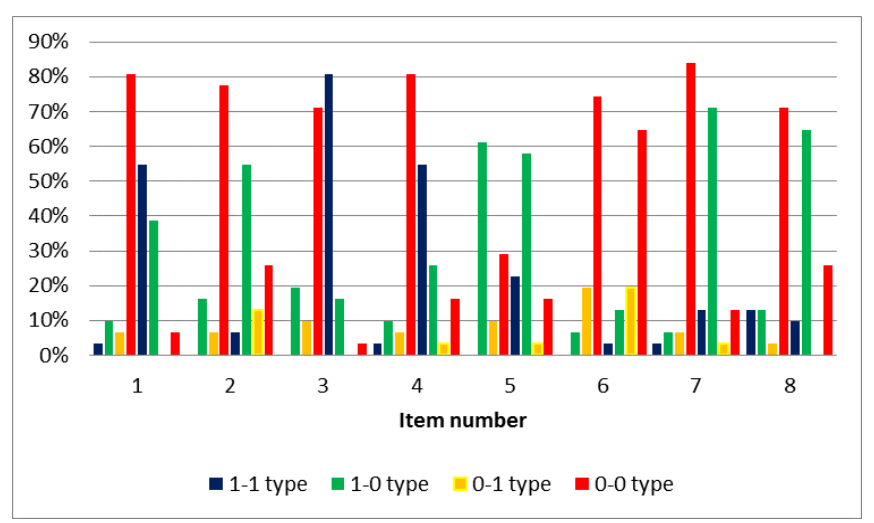

Fig. 3. Percentage Chart distribution of student pretest answers on salt hydrolysis material with a diagnostic test of a two-level multiple choice.

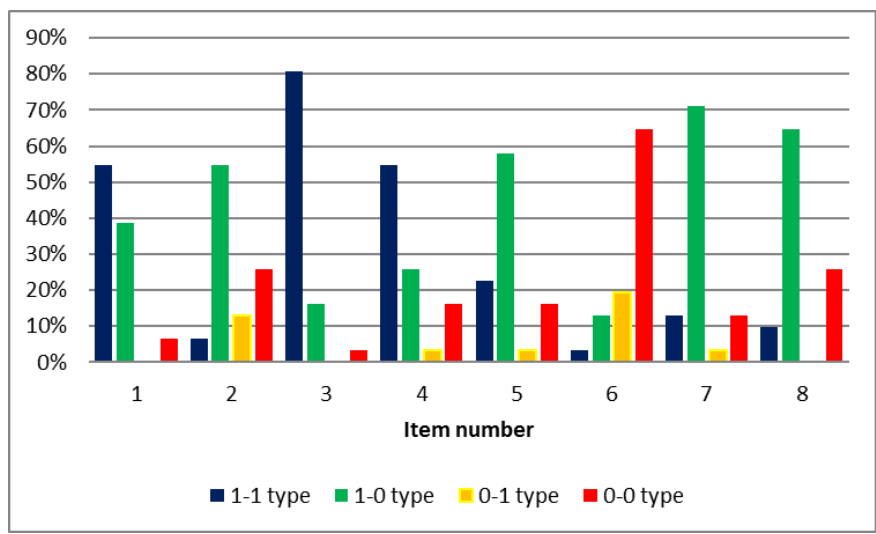

Fig. 4. Percentage Chart distribution of students' posttest answers on salt hydrolysis material with a diagnostic test of a two-level multiple choice.

The concept with a significant increase is the concept revealed in questions number 1, 3 and 4. Questions number 1, 3 , and 4 have the most percentage of type 11 answers namely $54.84 \%, 80.65 \%$, and $54.84 \%$. From these data, it can be seen that there are already many students who fully understand the concepts asked in items 1.3, and 4. The concepts revealed in questions number 5.7, and 8 have a significant increase in answer to type 10 i.e. successively by $58.06 \%, 70.97 \%$, $64.52 \%$. From these data, it is known that the concepts revealed in questions number 5.7, and 8 students understand the concepts at the macroscopic level but cannot connect the concepts at the submicroscopic level. The concept revealed by number 6 has the most type 00 answers that is equal to $64.52 \%$, this value has a decrease from the pretest which has a percentage of $74.19 \%$, meaning that only a few students answered correctly on question number 6 . The concept revealed in number 6 it is not discussed in the strategies and worksheets used, so that more students do not understand the concepts being asked.

Viewed from these 8 questions, in general, students experience a change in mastery of concepts after implementing an instructional learning strategy with POE even though a significant increase only occurred in a few concepts, but the results of the analysis of the answers showed that some students did not understand the level of submicroscopic level in the concept of salt hydrolysis. This shows students have not fully understood the concepts that have been learned so that they cannot explain the submicroscopic level correctly.

\section{B. Students' Science Process Skills After Learning Use An Intertextual-Based Strategy With POE on the Concept of Salt Hydrolysis}

The science process skills (SPS) aspects developed in the strategy are adjusted to the characteristics of the salt hydrolysis material, POE learning steps and basic competency skills, therefore eight aspects can be developed, namely predicting aspects, observing aspects, measuring aspects, classifying aspects, aspects of designing experiments, aspects of interpreting data, aspects of communicating the results of an experiment, and aspects of concluding. SPS aspects, SPS 
indicators and learning activities on the SPS aspects can be seen in table 4.

TABLE IV. SPS ASPECT, SPS INDICATORS AND ACTIVITIES DEVELOP IN THE STRATEGY

\begin{tabular}{|c|c|c|}
\hline SPS aspect & \begin{tabular}{|l} 
SPS Indicators \\
\end{tabular} & Learning Activities \\
\hline observation & $\begin{array}{l}\text { 4.11.1. Conduct observations of the acid-base } \\
\text { properties of salt solutions }\end{array}$ & Students conduct experiments on the acid-base properties of salt solutions \\
\hline Measuring & 4.11.2. Measuring the $\mathrm{pH}$ of a salt solution & \\
\hline Predicting & $\begin{array}{l}\text { 4.11.3. Predict the acidic, basic, or neutral nature of a } \\
\text { salt solution. }\end{array}$ & $\begin{array}{l}\text { Students predict individually the acid-base properties of the } \mathrm{NH}_{4} \mathrm{Cl} \text { solution, } \\
\mathrm{CH}_{3} \mathrm{COONa} \text { solution, } \mathrm{NH}_{4} \mathrm{CH}_{3} \mathrm{COO} \text { solution and }\left(\mathrm{NH}_{4}\right)_{2} \mathrm{CO}_{3} \text { solution } \\
\text { according to students' initial knowledge. }\end{array}$ \\
\hline Classifying & Classifying salt solution & Students group the salt solution based on the acidic nature of the base \\
\hline Communicating & $\begin{array}{l}\text { 4.11.5. Presenting experimental results for the nature } \\
\text { of salt solutions in tabular form. } \\
\text { 4.11.9 Communicate the results of discussions on the } \\
\text { calculation of the } \mathrm{pH} \text { of the salt solution }\end{array}$ & $\begin{array}{l}\text { Students fill in the experimental data in the safety table } \\
\text { Students submit the results of discussions on the calculation of the } \mathrm{pH} \text { of the } \\
\text { salt solution with the whiteboard media }\end{array}$ \\
\hline Experimentation & 4.11.6. Design an experimental acid-base salt solution & $\begin{array}{l}\text { Students write down the tools and materials needed to conduct an } \\
\text { experiment to test their predictions } \\
\text { Students make experimental work procedures for determining the acid-base } \\
\text { properties of a salt solution }\end{array}$ \\
\hline $\begin{array}{c}\text { Data } \\
\text { Interpreting }\end{array}$ & $\begin{array}{l}\text { 4.11.7. Explain experimental data on the acid-base } \\
\text { properties of salt solutions presented in tabular form }\end{array}$ & $\begin{array}{l}\text { Students explain what makes the salt solution acidic and basic when viewed } \\
\text { from }\left[\mathrm{H}_{3} \mathrm{O}^{+}\right] \text {or }\left[\mathrm{OH}^{-}\right]\end{array}$ \\
\hline Inference & $\begin{array}{l}\text { 4.11.8. Make conclusions about the acid-base } \\
\text { properties of the saline solution based on experimental } \\
\text { results. }\end{array}$ & $\begin{array}{l}\text { Students discuss in groups to formulate conclusions on the worksheet and } \\
\text { present it verbally by one of the group members }\end{array}$ \\
\hline
\end{tabular}

From the 8 aspects developed there are 7 aspects measured, these aspects are observing, measuring, predicting, classifying, communicating, designing experiments and interpreting data. With the SPS pretest pretest instrument and the results of data analysis it was found that all aspects increased on average. The results of the analysis are outlined in the graph in the following figure:

Overall, students' science process skills have increased in all aspects measured, namely in the aspect of observing the average aspect increased from $67.74 \%$ to $74.19 \%$, in the aspect of measuring the average increased from $79.03 \%$ to $88.71 \%$, in the aspect of classifying the average an increase from $85.48 \%$ to $87.10 \%$, in the aspect of predicting an average increase from $93.55 \%$ to $98.39 \%$. The communicating aspect increased on average from $67.74 \%$ to $72.58 \%$, on the aspect of designing and experimenting the average increased from $60.75 \%$ to $61.29 \%$, on the aspect of interpreting the data the average increased from $73.12 \%$ to $82.80 \%$ (see figure 5).

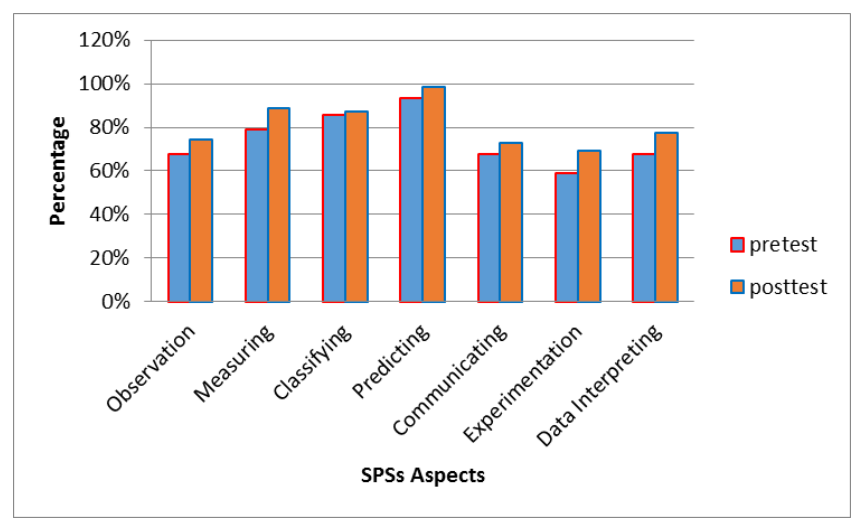

Fig. 5. Chart analysis of the results of students' pretest and posttest science process skills.

\section{CONCLUSIONS}

After intertextual-based learning with POE models in salt hydrolysis, the mastery of students' concepts in salt hydrolysis material has increased with the distribution of student achievement: 1 student in the high category, 12 students in the medium category, and 18 students in the low category. From the results of data analysis of science process skills, it was found that students' science process skills had increased from an average of $74.31 \%$ to $81.11 \%$.

\section{REFERENCES}

[1] J.K. Gilbert and D.F. Treagust, "Introduction: Macro, submicro and symbolic representations and the relationship between them: Key models in chemical education," In Multiple representations in chemical education (pp. 1-8). Springer, Dordrecht, 2009.

[2] Ministry of Education and Culture of Indonesia, Nomor, (22). Standar Proses. Jakarta: Depdikbud, 2016.

[3] A.P. Sukarno and I. Hamidah, "The profile of science process skill (SPS) student at secondary high school (Case study in Jambi)," International Journal of Scientific Engineering and Research (IJSER), vol. 1, no. 1, pp. 79-83, 2013.

[4] C. Keil, J. Haney, and J. Zoffel, "Improvements in student achievement and science process skills using environmental health science problembased learning curricula," Electronic Journal of Science Education, vol. 13, no. 1, 2009.

[5] Tawil and Liliasari, Keterampilan - keterampilan sains dan implementasinya dalam pembelajaran IPA. Universitas Negeri Makassar. Makassar, 2014.

[6] S. Özgelen, "Students' science process skills within a cognitive domain framework," Eurasia Journal of Mathematics, Science \& Technology Education, vol. 8, no. 4, pp. 283-292, 2012.

[7] R. White and R. Gunstone, Prediction-observation-explanation. Probing understanding, 4, 1992. 
[8] Febriyanti, Strategi Pembelajaran Intertekstual Berbasis Predct-ObserveExplain (POE) pada Proses Eksoterm dan Endoterm Untuk Meningkatkan Penguasaan Konsep dan Keterampilan Proses Sains Mahasiswa Calon Guru Kimia. (Tesis). Universitas Pendidikan Indonesia, Bandung, 2019. unpublished

[9] Nopiharga, Implementasi strategi pembelajaran intertesktual pada materi reaksi redoks kelas X. (Skripsi). Universitas Pendidikan Indonesia. Bandung, 2014.

[10] M. Ulfah, Pengembangan Strategi Berbasis Intertekstual dengan PredictObserve-Explain (POE) pada Materi Hidrolisis Garam untuk Meningkatkan Penguasaan Konsep dan Keterampilan Proses Sains Siswa. (Skripsi). Universitas Pendidikan Indonesia, Bandung, 2018.

[11] J.W. Creswell, Research design: qualitative, quantitative and mixed methods, 2009.
[12] H. DhiyaUlhaq, Profil Model Mental Siswa pada Materi Hidrolisis Garam Menggunakan Tes Diagnostik Model MT. (Skripsi). Universitas Pendidikan Indonesia, Bandung, 2018.

[13] Monica 2015.

[14] Ngoh 2009.

[15] A.H. Zeidan and M.R. Jayosi, "Science Process Skills and Attitudes toward Science among Palestinian Secondary School Students," World Journal of Education, vol. 5, no. 1, pp. 13-24, 2015.

[16] R.R. Hake, Interactive-engagement versus traditional methods: A sixthousand-student survey of mechanics test data for introductory physics courses. American journal of Physics, vol. 66, no. 1, 64-74, 1998. 